\title{
Child Social Protection: Accessible by All or None? A Qualitative Analysis of Child Protection Workers Views in Albania
}

\author{
Irida Agolli Nasufi ${ }^{1} \&$ Anxhela Bruçi ${ }^{1,}{ }^{*}$ \\ ${ }^{1}$ Faculty of Social Sciences, University of Tirana, Tirana, Albania \\ *Correspondence: Faculty of Social Sciences, University of Tirana, Tirana, Albania. E-mail: \\ anxhelabruci1@gmail.com
}

Received: November 21, $2020 \quad$ Accepted: December 4, $2020 \quad$ Online Published: January 10, 2021

doi:10.5430/wjss.v8n1p1 URL: https://doi.org/10.5430/wjss.v8n1p1

\begin{abstract}
Limited research has focused on the challenges of child protection workers involved in the social protection system in Albania. Despite the changes that social protection has undergone over the last years, obstacles arise in the implementation process. Regardless of the strategies and programs targeting child protection in Albania children have not been protected from exploitation and other life-threatening risks. Mainly non-governmental organizations and stakeholders who support the child social protection system in Albania have been involved in continuous efforts to identify what is missing, and what needs to improve regarding the child social protection system. This paper presents the experiences of child protection workers on how the current social protection system responds to the needs of children and their families. The data was collected from 10 child protection workers in Albania using in-depth semi-structured qualitative interviews. This research found that there is a gap in the distribution of services between urban and rural areas preventing beneficiaries who live in rural areas to access social services. Some of the major challenges that emerged by the majority of interviewees were lack of training, weak institutional cooperation accompanied by the need for emergency centers to assist children at risk of exploitation and abuse.
\end{abstract}

Keywords: child welfare, social policy, risk, income support/social assistance

\section{Introduction}

This research examines the challenges child protection workers face in the child social protection system in Albania. Through the use of qualitative interviews, the experiences of 10 child protection workers have been captured. The results provide a more focused exploration of the differences in the accessibility and quality of child social protection. Additionally, this research explores the level of cooperation among public, private, and non-governmental organizations that support the child social protection system in Albania. Through this paper, it was aimed to explore the role of child protection workers in the child social protection system and what is required to make child social protection more accessible. This research aimed to respond to two main questions. First, what are the challenges faced by child social protection workers in the child protection system in Albania? Second, how can the child social protection system become more accessible for the service beneficiaries? This research adds to the development of a more accessible child social protection system and to the discussion of the role of child social protection workers in ensuring that protection systems are accessible.

This paper first provides a context of child social protection in Albania. Later, it follows with the legislation that supports the child social protection system and the recent changes reflected in legislation. It follows with the challenges faced by child protection workers. As explained in the upcoming paragraphs social protection system in Albania is mainly focused on the vulnerable and marginalized groups of society such as children born in poverty, ethnic minority groups, and persons with disabilities. Ethnic minorities and children born in poverty tend to be residents of geographically deprived and rural areas, resulting in the majority of policy and programming efforts being drafted in absence of the beneficiaries. The methodology section provides information on the process followed to conduct this research. Last, conclusions are presented focusing on the need for policy development and strengthening the role and opportunities of social protection workers in Albania. 


\subsection{Relevant Scholarship}

\subsubsection{Child Social Protection Overview and the Context of Albania}

Social protection services are a crucial aspect to protect children from any possible harm (Cabran, Finelli, \& Bradford, 2015; Institute of contemporary studies, 2016). Various studies consider the process of developing social protection has undergone various paths, from being considered as a short term intervention that provides safety to a crucial tool for providing sustainable responses to social problems (Brière \& Rawlings, 2006; Hulshof, 2019; Mahendru \& Tasker, 2020). Social protection refers to all mechanisms that are responsible to ensure the welfare of the citizens, by preventing them from facing with the effects that age, illnesses, disability, unemployment, and other issues might bring. In recent years, social protection is seen as an instrument of policy and programs which focus on the social problems of citizens and address their needs through the use of such instruments (Devereux et al., 2013; François-Xavier, 2013). Social protection is a specific target of the 2030 Agenda, under the first Sustainable Development Goal for Poverty Eradication (FAO, 2015, 2017). The role of social protection is crucial given the impact it has on the lives of the most vulnerable ones. One of the main aims of social protection in Albania is to provide safety to vulnerable groups and respond to their needs (Delaney, 2013).

In the first years, when social protection started being implemented in Albania, its focus was on the provision of financial aid through cash payments. However, in recent years, with the law on social care services of 2016, the need to provide social services has been more evident. For example, the recent 2019-2022 social protection strategy focuses on the provision of social services. Research shows that applying cash payments to replace social protection services have been used to reduce the effects of poverty and vulnerability (Chzhen, 2017; Marchal, Marx, \& Van Mechelen, 2014). Nevertheless, through cash payments, social protection systems lack to identify and address various aspects that contribute to poverty and vulnerability, by only providing a short term response. When the focus of social protection is in the provision of financial assistance, some complexities are concealed, and the vulnerabilities as a result of poverty and marginalization hinder the path of escaping poverty and vulnerability.

Despite the efforts to design and implement an effective child social protection system, more child-oriented approaches are needed focusing on innovative methods and setting indicators to evaluate the effectiveness of the system (UNICEF, 2011; Ymeraj, 2016). In rural areas of Albania, infant and child mortality rates are twice the national average, and even if the total burden of disease for children aged from one to four years old has reduced significantly, it remains the highest in the Southeastern European countries (Albanian Demographic Health Survey, 2018; Institute of Public Health, 2014).

Given the complexity of service delivery within various geographical areas and the lack of trained staff, the provision of social protection services is considered problematic and it faces various challenges. An effective social protection system requires the involvement of a qualified and experienced workforce to support the system (Delaney, 2013). Recent studies in South-Eastern Europe show that the social protection workforce is not recognized fully by the public and the service beneficiaries (Akesson, 2016). Moreover, François-Xavier (2013) claims that social protection programs require a certain level of professionalism, expertise, and resources which are difficult to find in the majority of developing countries.

Recent changes on social protection in Albania have been reflected in the Law on Social Services nr. 121/2016 for services of social care in the Republic of Albania, which clarifies the decision-making lines and functions of local and central government institutions. For the first time, this law defined the types of social services, and enabled the establishment of rules for their provision, aiming to improve the lives of individuals and families in need. Social protection is provided through community social services, shelters, and family assistance services. In the context of the new law on fiscal and administrative decentralization in Albania, essential public services are being delegated to local governments, including social care services, where the creation of new financing and effective management mechanisms for service delivery arises (Dhëmbo, 2014, 2015; Tahsini, 2017). However, some municipalities do not provide any social services in their territory yet. Moreover, the staff at the municipal headquarters lacks experience in the administration of social protection. The current approach has involved transferring the responsibility and authority of social care institutions to the local government.

\subsubsection{Domestic Legislation and Strategies in Place to Support Social Protection Services for Children in Albania}

Child protection aims to promote, protect, and fulfill children's rights to protection as laid down in the United Nations Convention on the Rights of the Child. The Albanian Law on Child Rights defines child protection as the prevention and response to violence, abuse, exploitation, and neglect of the child, including the prevention of kidnapping, sexual abuse, trafficking, and child labor. The responsible institutions take concrete measures to 
cooperate, and share responsibilities with the central and local government, social services professionals, and beneficiaries to strengthen the child social protection system. The United Nations Convention on the Rights of the Child entered into force on 2 September 1990. As stated in article 7 of the Convention, the state parties shall ensure the exercise of these rights under their national legislation. Law no.121/2016 on social care services in the Republic of Albania sets rules on the provision of social protection services that help the well-being and social inclusion of individuals and families in need of social care. Additionally, the law no. 9642, dated 20 November 2006, on the ratification of the Council of Europe Convention on Measures against Trafficking in Human Beings, aims to find a sustainable solution from institutions to provide services for abused or trafficked children, providing specific measures and actions to assist and support children, victims of exploitation or trafficking, until their physical and psychological recovery.

Legislative measures to ensure the creation of responsible mechanisms were reflected in law no.10 347, dated 4.11.2010 for the protection of child rights, which defines the responsible mechanisms that guarantee the protection for all children. In this law, institutional mechanisms for the protection of child rights seek cooperation among different levels of entities. However, the law on the protection of child rights does not anticipate the operation and the combined effort of such units. In 2017 the Albanian Government approved the National Agenda for Child Rights, a strategic document that envisions the support of favorable conditions for the healthy, physical, and psychosocial development of children, social inclusion, and participation in all processes, respecting the best interest of the child. The National Agenda sets out the priorities of state institutions in the area of child rights and at the same time, a framework to monitor the progress of the Albanian Government towards the fulfillment and protection of child rights in social protection units.

Regarding the protection of children and the fulfillment of their rights, law no. 18/2017, defines the rights and protections that every child benefits, and the mechanisms that guarantee the effectiveness of the protection of such rights. Through this law, available measures are in place to ensure that children exercise their rights based on their highest interest. Likewise, it considers different arrangements of protection of children, such as the right to social protection, protection from all forms of violence, against economic exploitation, against the use of narcotic substances and psychotropic substances, protection from trafficking and any form of sexual exploitation, and abuse, protection from involvement in armed conflicts, protection from torture, punishment, cruel, inhuman or degrading treatment and protection of a child who has been deprived of his or her liberty.

After twenty years of continuous efforts to fulfill and respect child rights, in 2012 child protection units were set up for the first time in Albania. However, child protection units are not the responsibility of the central government. The municipalities are responsible for child protection units, each municipality has to define its budget for the operation of its child protection unit. This way of independent functioning results in a lack of universal child social protection services. Moreover, some municipalities are allocating fewer funds to their unit compared to others, which limits the social services that children and their families can access in particular geographical areas. In terms of strategies and agreements for child social protection, the National Strategy for Social Protection, 2019-2022 is being implemented. Additionally, the Council of Europe Strategy on Children's Rights 2016-2021, and the national agenda for children's rights 2017-2020 aim to promote children's rights in Albania and strengthen their protection, by incorporating innovative and inclusive approaches in their responses.

\subsubsection{Challenges in the Child Social Protection System in Albania}

Despite the aim of an accessible and inclusive social protection system in Albania, several challenges arise. Such challenges are identified within the implementation of legislation and policies, followed by restricted budgeting and lack of professional training. For example, the Commissioner for human rights in the Council of Europe emphasized the need for social protection authorities to ensure the effective implementation of the legislation in place (Mijatović, 2018). Additionally, capacity building is crucial for child protection workers. According to UNICEF (2019), there are 236 child protection workers in Albania, not all of them are trained and specialized in social work, lacking adequate knowledge of specific procedures working with children. Moreover, one child protection worker is employed for every 3,000 children. Given the crucial role, that child protection workers have in the protection of children from violence, abuse, neglect, and exploitation, strengthening capacity building is an important aspect.

Lack of trust in the child social protection system and limited opportunities for development in rural areas might be one of the reasons birth rates in Albania are declining from year to year (Central Intelligence Agency, 2017; Institute of Statistics, 2011, 2015; Macrotrends, 2020). Even if the number of young people aged sixteen to twenty-four years old keeps increasing in Albania, the trend is not the same for children below the age of fifteen (Institute of Statistics, 2011, 2015, 2018). In terms of education, starting from the age of six years old children in Albania are obliged by the 
state to follow nine years of compulsory education, which makes compulsory education to end at the age of sixteen. Since compulsory education has the mission to advance the intellectual, creative, practical, and physical skills of students, united efforts are needed to ensure and monitor the quality of education in Albania, and to make it accessible for children at risk of exploitation and poverty (Hanushek, 2010; World Bank, 2014).

Children at risk of exploitation and from minority groups in Albania struggle to access social protection services, such barriers become more evident they live in rural areas. First, minority ethnic groups continue to be the poorest and have benefited the least from the economic growth of the country (European Social Policy Network, 2019; Save the Children, 2012). Second, Albania is one of the poorest and less developed countries in Europe, increasing the challenges of initiating and implementing multidisciplinary systems of social protection (European Social Policy Network, 2019; Eurostat, 2018; International Monetary Fund, 2019). Third, more than half of the children whose families receive financial aid from the government, are not able to meet five of the most crucial needs such as nutrition, health care, education, clean drinking water, and housing (Bali et al., 2016; World Bank, 2019).

Children are considered as a vulnerable category when it comes to poverty, their needs, thoughts, and requests might be considered as irrelevant by their parents or carers (Ferguson, 2017; International Policy Centre for Inclusive Growth, 2018). The State Social Services Unit in Albania is responsible for the staff who provides social services in different institutions on a national level. Apart from the services provided by the State Social Services Unit, social services in Albania are provided by NGOs as well. However, the services provided by the State Social Services Unit face challenges regarding the capacities of human resources and limited professional experience mainly because of high rates in staff circulation (Dhembo, 2014, 2015; Qendra Fëmijët Sot, 2013).

Despite the existence of child protection units in the majority of the municipalities in Albania, they are not fully operational. For example, they may have only one staff member who might be inexperienced in social work and has to deal with a high number of caseloads (Cabran, Finelli, \& Bradford, 2015; Dhembo, 2015). Moreover, only 28\% of the required child protection workers have so far been appointed and only $38 \%$ of the appointed ones are active and managing cases related to children at risk (UNICEF, 2019). In a study conducted by Dhembo (2018) On the other hand, challenges arise when child protection workers who have acquired long professional experience in social services have no adequate education in social work. Moreover, Mijatović (2018) notes that some children at risk of violence and exploitation are not being aware of where to address when they want to seek help and in particular how they can be protected if they have been abused by their family members.

The quality and standards of services are an ongoing challenge for the social protection of children in Albania. The law on social services that entered into force on the 24th of November 2016, defined for the first time the list and types of social services resulting in the establishment of rules for the provision of services for individuals and families in need. Social services in Albania are mainly provided as daycare and residential care services and are funded by the state budget. At the national level, there are 29 public social service centers out of which 23 are residential and 6-daycare centers, all limited to 13 municipalities (Ymeri, 2018). In this context, the establishment of the Social Fund enables each municipality to establish new social services in the territory for vulnerable groups, guaranteeing minimum social services as well as the sustainability of current services, according to the needs of the territory, specified in the Social Plan.

Social services provided by NGOs are mainly funded by international and local NGOs. The provision of social services differs from the perspective of public institutions that tend to be more institutionalized. On the other hand, NGOs are subject to donor funding, which implies that there are serious gaps in service coverage, as well as risks of shortage in their funding. While the process of deinstitutionalization requires intensification, current services and residential centers need to be under an ongoing monitoring scheme. The authorities are also called upon to ensure better coordination at different levels in charge of the protection of children's rights, as well as sufficient staff and expertise to provide child-focused social services at the local level.

The interviews conducted with child protection workers enabled a more focused exploration of their direct experiences in the child protection system in Albania. The aim was to explore and gain a deep meaning of the child protection system and the areas that need to be improved to make the system more accessible for the beneficiaries. In the methodology section, a more detailed description is provided regarding the process followed to access the participants and conduct the research. 


\section{Methods}

This study used a qualitative methodology that focused on the exploration of child social protection from the direct views of child protection workers. The use of qualitative research instruments such as semi-structured in-depth interviews enabled us to explore the experiences of interviewees' by including the observations of the interviewer during the interviewing process (Tracy, 2020). Qualitative research allows a deep exploration, which reveals the results of specific interventions (Vaismoradi et al., 2016). This paper aims to respond to the research question of how the child social protection system in Albania meets the needs of the service beneficiaries. This research did not aim to be representative of all the population of child protection workers in Albania. To define the sample for this research purposive sampling was used based on some criteria to maximize the variety in terms of years of experience, city, and expertise of child protection workers. The sample was accessed through contacts with municipality units and non-governmental organizations. This research involved 10 child protection workers with at least five years of experience and expertise in child protection. From a total of 10 participants, 8 were females and 2 were male. Despite the aim to have an equal representation of female and male child protection workers, that was not possible given that more females are involved in this sector.

\subsection{Interviewing Process and Ethics}

The participants were initially contacted and provided with an information brief, which included the aim, objectives, and methodology of the research. The consent form was sent via email two weeks before the interview. The consent form emphasized that participation is anonymous and confidential. To respect the anonymity and confidentiality of participants the transcripts were coded with numbers and their affiliation was not included in the results and discussion section to prevent any possible identification of their identity. The interviewing phase started in November 2019 and ended in January 2020. The interviews were conducted face to face and lasted between 40 to 60 minutes. For the analysis of the interviews, codes were created, which helped to focus on the analysis process and to respond to the research questions.

\subsection{Data Analysis}

The data was analyzed using a thematical analysis approach following Vaismoradi et al. (2016) steps of initialization, construction, rectification, and finalization. First, the interviews were transcribed and codes were assigned to each section of the transcripts. Second, the data were compared with each transcript and it was categorized based on what the interviewees have shared. Third, themes were created and data that was responding to the research question was prioritized. Last, the storyline was developed, connecting the themes with the topic and presenting them to create a better understanding of the issue.

\section{Results}

\subsection{Results and Discussions}

This section presents and discusses the results derived from 10 semi-structured qualitative interviews with child social protection workers. The results cover issues related to the needs of beneficiaries, innovative approaches in the child social protection system in Albania, decision making and the involvement of service beneficiaries, challenges experienced in the child social protection system, and suggestions for the improvement of the system.

\subsection{Needs of the Beneficiaries and How Their Needs Are Met}

The interviewees were asked about the needs of the service beneficiaries and to what extent such needs were met by their organizations. That contributed to an overview of the services provided by their organizations and how they identified the needs of the beneficiaries. Among the most emphasized issues were the safety of children, distribution of service throughout the entire country, a strong family system to support the wellbeing of their children. More specifically, some of them stated:

"The coordination between municipalities to distribute the services where they are needed would increase the services, also coordination would help set the responsibility for the provision of the services to the responsible actors (Child protection worker (a), Tirana)".

Additionally, some of the child protection workers stated that they have assisted in filling documentation for beneficiaries that required shelter in emergency or rehabilitation centers, in cooperation with the hospital, and other related authorities:

"We need inclusive environments for children at risk and those who require rehabilitation services 
(Child protection worker, Diber)".

Emphasis was given on the creation of more emergency centers throughout Albania:

"Emergency centers at least in the biggest cities of the country [...] to accommodate children at risk, especially during the summer season in coastal cities where child labor is widespread (Child protection worker (c), Tirana)".

Lack of access to health care and information, accompanied by critical living conditions are considered as common problems faced by marginalized families, a professional from the public sector shared:

"Without a proper structure that evaluates and monitors services, the needs of beneficiaries cannot be properly assessed [...] especially needs for services for children with disabilities and in conflict with the law (Child protection worker (b), Tirana)".

Lack of access to health care, limited information, and the need for emergency centers were among the most raised concerns by the interviewees. Research shows that social protection services are a crucial aspect to protect children from possible harms that might arise because of their vulnerability, therefore, there is a need for more child-focused approaches. Social protection authorities in Albania should implement the legislation on social protection given the fact that more than half of the families who receive financial aid from the government live below the minimum living standards (Bali et al., 2016; Mijatović, 2018; World Bank, 2019).

\subsection{Innovative Approaches towards Child Social Protection Services}

This section explored innovative approaches used by child protection workers. The interviewees shared innovative approaches used during their work, which have been designed and implemented by local authorities and NGOs. In some cases, such services were geographically inaccessible. A child protection worker mentioned that they have initiated a phone application that can be used by citizens in Albania to report different cases of child abuse:

"We have recently included innovation in our functional 24-hour hotline and in our phone application which we developed in partnership with another NGO (Child protection worker (d), Tirana)".

While others focused their innovative intervention in their work directly with children:

"Considering children as leaders and involving them in different social activities to motivate them by using methods of reflection helps them to look at their future with hope (Child protection worker, Kruje)".

Another child social protection worker stated that they have focused their innovative approach on increasing the capacities of children from an early stage to be able to access the labor market:

"Our organization has created the Employment Counseling Cycle for children aged from 15 and up as a new innovative idea for choosing a preferred profession and acquiring the necessary skills (Child protection worker, Elbasan)".

However, the majority of interviewees viewed innovation more in terms of cooperation between professionals in the public system:

"Part of our institution are specialized teams dealing with children living in streets (Child protection worker (e), Tirana)".

Involving children while initiating social services is crucial, and is seen as an innovative approach by social workers (Ferguson, 2017; International Policy Centre for Inclusive Growth, 2018). Furthermore, new legislation in place for the provision of social services delegated the execution of essential public services to local governments, including social care services (Dhëmbo, 2014, 2015; Tahsini, 2017). Such changes have been perceived as problematic and not effective in the administration of social services in Albania.

\subsection{Decision Making and Involvement of Service Beneficiaries}

Child protection workers expressed that the system and parents had several expectations of them, without considering the available financial means. on place. Another common issue identified was linked to the necessity of involving beneficiaries when decision making takes place. The majority of child protection workers stated that beneficiaries are involved in the consultation process and that their services have been changing based on the needs of the beneficiaries:

"We take into account their opinions, in this way they get empowered and take an active role in the decision making (Child protection worker, Elbasan)". 
From the perspective of a non-governmental organization, more child tailored approaches were followed to include service beneficiaries in decision making:

"We had a situation recently when we changed the video we were working on because we did not ask from the beginning the opinion of the children involved in the project, the children laughed and said that the music was old fashioned (Child protection worker (b), Tirana)".

Despite the decisions that are taken by the multidisciplinary team, which evaluates the case and decide on new services that need to be added to the package:

"During the consultation phase, we have a group of representatives to make sure that we include our target group in the decisions (Child protection worker, Diber)".

The role of families in the creation of awareness campaigns and meetings was emphasized by a child protection worker:

"With professionals and community leaders we create community plans, we cooperate with businesses,

NGOs, and volunteers. In some cases, a group of parents organized meetings and awareness campaigns, but this is not always possible (Child protection worker (e), Tirana)."

Decisions are made based on the standards for the community centers established by the State Social Service and the law 121/2016 on community services. Ethnic minorities, particularly Roma and Egyptian minorities continue to be the poorest and have benefited the least from the economic growth of the country (European Social Policy Network, 2019; Save the Children, 2012). Aiming to empower children and their families to actively seek the protection of the rights is crucial, however, it remains challenging given that the majority of children whose families receive financial assistance struggle to meet their basic needs (Bali et al., 2016; World Bank, 2019).

\subsection{Challenges Experienced in Child Social Protection Services}

During the interviewing phase, it resulted that minority groups in Albania were facing difficulties to access social services. Moreover, they considered dependency from the service users as a problem that was inherited by organizations providing services for children and their parents exploiting their children. Also, children in contact with the law, due to changes in legislation are exempted by some offenses, therefore they are used to commit criminal offenses in the name of adults. More parenting programs were requested:

"Parents lack education [...] they cannot access transportation so they lose the chances for some services out of their area (Child protection worker, (b), Tirana)".

Bureaucracy was considered as an important aspect, which could act as a barrier within the social protection system in Albania:

"Long application procedures, lack of information on services $[\ldots]$ the restriction on selection criteria excludes a large proportion of families in need (Child protection worker, Kruje)".

Similarly, from the perspective of public institutions bureaucracy was considered as an ongoing barrier when accessing services:

"Bureaucracy in public institutions, legal problems especially in matters of parental custody, all of which translate into barriers and often deny access to services (Child protection worker (c), Tirana)".

Lack of information and weak systems was mentioned by the majority of the interviewees. Some of the child protection workers stated that they require more training and capacity building initiatives for them:

"Capacity building of service providers to understand the needs of children at risk, if a child goes to report to the police, they ask him to go accompanied by a parent (Child protection worker (e), Tirana)".

The process of adapting to a new environment where children will receive services takes time and is dynamic:

"Lack of needs assessment by the child protection workers, negligence and irrelevant training lead to missing cases that are in an emergency (Child protection worker (a), Tirana)".

The majority of child protection workers stated that vulnerable families faced financial and geographical barriers, which were among the strongest reasons for families to not be able to access services. For children living out of urban areas, transport and weak infrastructure stepped as a challenge to reach different services or seek protection as they lacked financial and logistical means to do so. The State Social Services unit in Albania is responsible for the staff of institutions that provide social services on a national level. Apart from the services provided by the State Social Services Unit, social services in Albania are also provided by NGOs. However, the services provided by the 
state face challenges regarding the capacities of human resources and lack of professional experience because of the high rates in staff circulation, and children not being aware where to seek protection in case of abuse (Dhembo, 2014, 2015; Mijatović, 2018; Qendra Fëmijët Sot, 2013).

\subsection{Suggestions for the Improvement of Child Social Protection in Albania}

The recommendations provided by child protection workers were focused on capacity building of staff, an increase of emergency centers, coordination of different agencies for the unification of their responses, and setting up dedicated centers to ensure that service beneficiaries receive services within their city, to avoid travel and additional costs:

"Increase the number of emergency centers [...] municipalities should adopt social plans to benefit from the Social Fund (Child protection worker (d), Tirana)".

From the perspective of non-governmental organizations it was emphasized the importance of cooperation between the relevant institutions to avoid any ambiguity and neglect of respective competencies, increasing the capacity of child protection workers in each institution:

"Each institution has to know their responsibilities [...] it is important to strengthen the services distributed in rural areas, mental health support for children and their families (Child protection worker, NGO, Elbasan)".

The role of the family was considered important to ensure sustainability. Child protection workers called for more cooperation between families and child protection workers were suggested, creating campaigns to increase hope, and empowerment programs for parents and children:

"Closer contacts of social workers and psychologists with parents, meetings with more frequent multidisciplinary technical groups and higher involvement of NGOs [...] more cooperation between NGOs and state public institutions to exchange information between actors in case of referrals (Child protection worker, Kruje)".

The emphasis on building more specialized and dedicated centers was raised as well by professionals working in public institutions, a child protection worker noted:

"I suggest that each municipality has its center so every case receives services in their geographic area to avoid the movement of citizens and children (Child protection worker, Diber)".

Supporting the initiation of campaigns that focus on the empowerment of families and children might be a helpful approach to increase the capacities of child protection workers to focus on innovative responses that seek more cooperation with parents.

\section{Conclusions}

The findings of this research add to the knowledge regarding the needs of service beneficiaries, child protection workers, and the child protection system. More innovative and tailored responses will enable effectiveness in the system and strengthen collaboration between professionals. However, to achieve this, a multidisciplinary approach needs to be implemented and supported by professionals, families, and the government. Despite the importance of empirical research on social protection, remarkably few studies have been designed to provide empirical results regarding the service delivery and the child social protection system in Albania. Therefore, future research needs to address topics regarding the effectiveness of the child protection system and the challenges of service beneficiaries. This research found that child social protection was not accessible in all municipalities of Albania. Moreover, rural areas were excluded and difficult to reach, such geographical differences should inform policymaking and service delivery to better identify and meet the needs of children at risk. Therefore, a greater depth and breadth of information and research in this area is required to inform the policymaking process.

\section{References}

Akesson, B. (2016). The social service workforce as related to child protection in Southeast Europe. A regional overview report. Budapest, Hungary: Child Protection Hub.

Albanian Demographic Health Survey. (2018). Albanian demographic survey 20017-2018. Retrieved from https://dhsprogram.com/pubs/pdf/FR230/FR230.pdf 
Bali, D., Kuli-Lito, G., Ceka, N., \& Godo, A. (2016). Maternal and Child Health Care Services in Albania. Journal of Pediatrics, 177, 11-20.

Brière, B., \& Rawlings, L. B. (2006). Examining conditional cash transfer programs: a role for increased social inclusion? Social protection and labor discussion paper, no. 0603. Washington, D.C.: World Bank Group.

Cabran, M., Finelli, M., \& Bradford, B. (2015). Mapping and Analysis of the Albania CP System. Report on the functioning of the response to CP risks. Minneapolis: Maestral International.

Central Intelligence Agency. (2017). The world factbook: Albania. Retrieved 20 January, 2020 from https:/www.cia.gov/library/publications/the-world-factbook/geos/al.html

Chzhen, Y. (2017). Unemployment, social protection spending and child poverty in the European Union during the Great Recession. Journal of European Social Policy, 27(2), 123-137.

Council of Europe. (2016). Future of an integrated child system in Albania: The vision of how to improve children's outcomes in Albania through an effective and integrated child protection system. Council of Europe Experts.

Delaney, S. (2013). Vlerësimi i Njësive për Mbrojtjen e Fëmijëve (Assesment of the Child Protection Units). Tirana, Albania: World Vision.

Devereux, S., Roelen, K., Béné, C., Chopra, D., Leavy, J., \& McGregor, J. A. (2013). Evaluating Outside the Box: An Alternative Framework for Analysing Social Protection Programmes. IDS Working Papers, 1-26. https://doi.org/10.1111/j.2040-0209.2013.00431.x

Dhembo, E. (2014). Social European model in Albania: Public administration in Albania, between citizens and politics. Tirana: FES and IDM.

Dhembo, E. (2015). Initial study in the identification of practices for the protection of children and the needs of the staff for the protection of the children in Albania. Tirana: Terres Des Hommes.

Dhembo, E. (2018). Mapping of the basic child protection structures (at local level) and prioritization of their capacity building needs. Child Protection Hub for East Europe.

Dhembo, E., Akesson, B., \& Cheyne-Hazineh, L. (2019). Social work education in Albania: a developing landscape of challenges and opportunities. European Journal of Social Work. https://doi.org/10.1080/13691457.2019.1681365

Diwakar, K. V. (2009). Barriers and challenges in accessing social transfers and role of social welfare services in improving targeting efficiency: A study of conditional cash transfers. Vulnerable Children and Youth Studies, 4(1), 41-54. https://doi.org/10.1080/17450120903111883

European Social Policy Network. (2019). The Social Services Network in Europe. Retrieved from https://www.esn-eu.org/home/index.htm

Eurostat. (2018). Main GDP aggregates per capita. Eurostat: Brussels. Retrieved from https://appsso.eurostat.ec.europa.eu/

Ferguson, H. (2017). How children become invisible in child protection work: findings from research into day-to-day social work practice. The British Journal of Social Work, 47(4), 1007-1023.

Food and Agriculture Organization. (2015). The State of Food and Agriculture.

Fao, F. (2015). Social Protection and Agriculture: Breaking the Cycle of Rural Poverty. Rome: Food and Agriculture Organization, United Nations. Retrieved from www.fao.org/3/a-i4910e.pdf

Food and Agriculture Organization. (2017). FAO social protection framework promoting rural development for all. Rome: Food and Agriculture Organization, United Nations. Retrieved from http://www.fao.org/3/a-i7016e.pdf

François-Xavier, M. (2013). Social Protection as Development Policy: A New International Agenda for Action. International Development Policy, 4(2), 89-106.

Green, A. E., \& Aarons, G. A. (2011). A comparison of policy and direct practice stakeholder perceptions of factors affecting evidence-based practice implementation using concept mapping. Implementation Science, 6, 104-113.

Hanushek, E. (2010). The High Cost of Low Educational Performance. The long-run economic impact of improving PISA outcomes. OECD Publications.

Hulshof, H. (2019). Child participation in evaluating social protection projects: do global development actors walk the talk? Progress in Development Studies, 19(1), 1-20. https://doi.org/10.1177/1464993418805170 
Institute of contemporary studies. (2016). Supporting planning of social care services proposal on establishing a package of services in Albania and financing mechanisms. Tirana: Institute of contemporary studies.

Institute of Public Health. (2014). National Health Report-Health Status of the Albanian Population. Tirana: Institute of Public Health. from http://ishp.gov.al/wp-content/uploads/2015/04/Health-report-English-version.pdf

Institute of Statistics. (2011). Population and housing census in Albania: Preliminary Results. Tirana: Institute of Statistics INSTAT.

Institute of Statistics. (2015). Youth in Albania, challenges in changing times. Tirana: Institute of Statistics.

Institute of Statistics. (2018). Albania in figures. Tirana: Institute of Statistics.

International Monetary Fund. (2019). World Economic Outlook April 2019. Washington: International Monetary Fund.

International Policy Centre for Inclusive Growth. (2018). Social protection: meeting children's rights and needs. International Policy Centre for Inclusive Growth, 15(3), 1-53.

Macrotrends. (2020). Albania Birth Rate 1950-2020. Retrieved from https://www.macrotrends.net/countries/ALB/albania/birth-rate

Mahendru, R., \& Tasker, M. (2020). Introduction: Child sensitive social protection: Programmes and Policy Options. Global Social Policy, 20(1), 3-5. https://doi.org/10.1177/1468018119895430

Marchal, S., Marx, I., \& Van Mechelen, N. (2014). The Great Wake-up Call? Social Citizenship and Minimum Income Provisions in Europe in Times of Crisis. Journal of Social Policy, 43(2), 247-67.

Mijatović, D. (2018). Commissioner for human rights of the Council of Europe report following her visit to albania from 21 to 25 May 2018. Strasbourg: Commissioner for human rights.

Qendra Fëmijët Sot. (2013). Institucional analysis of the role, duties, responsibilities of the state social services unit in relation to the reform of social care services. Tirana: Qendra Fëmijët Sot.

Save the Children. (2012). Child rights situation analysis Albania. Tirana: Save the Children.

Tahsini, I. (2017). Reviewing existing quality mechanisms in child protection: Albania national report. Child Protection Hub. https://childhub.org/en/system/tdf/library/attachments/albania_web.pdf?file=1\&type=node\&id=29634

Tracy, S. J. (2020). Qualitative research methods: collecting evidence, crafting analysis, communicating impact (2nd ed.). Hoboken: John Wiley \& Sons.

UNICEF. (2011). Social Protection Strategic Framework: Integrated Social Protection Systems: Enhancing equity for children. New York: UNICEF.

UNICEF. (2019). Unifying practices, knowledge and skills to better respond to child protection concerns in Albania. Retrieved from https://www.unicef.org/albania/press-releases/unifying-practices-knowledge-and-skills-better-respond-child-pro tection-concerns

Vaismoradi, M., Jones, J., Turunen, H., \& Snelgrove, S. (2016). Theme development in qualitative content analysis and thematic analysis. Journal of Nursing Education and Practice, 6(5), 100-110.

World Bank. (2014). Cilësia e Arsimit dhe Mundësitë për Zhvillimin e Aftësive në Shqipëri Analizë e rezultateve të PVNN-së 2000-2012. Njësia për Sektorin e Arsimit Rajoni i Europës dhe Azisë Qendrore.

World Bank. (2019). The World Bank in Albania Overview. World Bank. Retrieved 20 November, 2019 from https://www.worldbank.org/en/country/albania/overview

Ymeraj, A. (2016). Boosting growth through social business: a state's or market's function. Balkan Journal of Interdisciplinary Research, 1(3), 49-59.

Ymeri. S. (2018). A review of local budget spending on social care services. United Nations Development Programme, Albania. 


\section{Copyrights}

Copyright for this article is retained by the author(s), with first publication rights granted to the journal.

This is an open-access article distributed under the terms and conditions of the Creative Commons Attribution license (http://creativecommons.org/licenses/by/4.0/). 